\title{
Biosynthetic Somatomedin C (SM-C/IGF-I) Increases the Length and Weight of Snell Dwarf Mice
}

\author{
SYLVIA VAN BUUL-OFFERS, IKUO UEDA, ${ }^{1}$ J. L. VAN DEN BRANDE \\ Department of Paediatrics, State University of Utrecht, University Hospital for Children and Youth, \\ Utrecht, The Netherlands
}

\begin{abstract}
An Escherichia coli derived somatomedinC/IGF-I preparation (rec-IGF-I) with an amino acid sequence identical to the natural IGF-I derived from human plasma, increases body length and weight, as well as the growth of several organs of Snell dwarf mice, when administered for 4 wk. After 2 wk of treatment rec-IGF-I (22.2 $\mu \mathrm{g} /$ day) induced a significant increase over buffer treated controls, to a comparable degree as obtained with bacterially synthesized human growth hormone (bhGH; $8.4 \mu \mathrm{g} /$ day). The weight/length ratio of rec-IGF-I and bhGHtreated dwarf mice after 4 wk of treatment were not significantly different. A significant increase over controls was obtained with both preparations. Organs with increased weights after bhGH treatment (brain; submandibular salivary glands; heart, liver, kidneys, thymus, and spleen) were also heavier after rec-IGF-I. Significance was only reached for the kidneys and the spleen and the musculus quadriceps femoris. Organ weights expressed as a percentage of body weight of bhGH and rec-IGF-I treated dwarfs were similar except for the relative weight of the heart of the bhGH group, which was significantly increased compared to the controls and the rec-IGF-I group. These data resolve the issue as to whether or not pure SM-C/IGF-I will induce growth in length and demonstrate the usefulness of recombinant IGF-I in the studies of growth regulation. (Pediatr Res 20: 825-827, 1986)
\end{abstract}

\[ \text { Abbreviations } \]
SM, somatomedins
IGF, insulin-like growth factors
bhGH, bacterially synthesized human N-terminal meth-
ionyl growth hormone

SM or IGF are thought to mediate the effects of growth hormone on body growth $(1,2)$. Partially purified SM-preparations have been shown to increase body length and weight as well as the growth of many organs of Snell dwarf mice $(3,4)$, deficient in growth hormone and thyroid-stimulating hormone. In addition these preparations had stimulatory effects on the ${ }^{35} \mathrm{~S}$ -

Received February 2, 1986; accepted April 15, 1986.

Correspondence Sylvia van Buul-Offers, Department of Paediatrics, State University of Utrecht, University Hospital for Children and Youth "Het Wilhelmina Kinderziekenhuis," Nieuwe Gracht 137, P.O. Box 18009, 3501 CA Utrecht, The Netherlands.

Part of this work was supported by the Dutch Foundation of Medical Research (FUNGO), Grant 900-528-033.

${ }^{1}$ Present address Fujisawa Pharmaceutical Co. Ltd., 1-6, 2-Chome, Kashima, Yodogawa-Ku, Osaka 532, Japan. sulphate and ${ }^{3} \mathrm{H}$-methylthymidine incorporation into their costal cartilage, osteochondral junction, and epiphyseal cartilage. Further purified SM-C/IGF/I has been reported to increase body weight of hypophysectomized rats as well as the incorporation of thymidine in epiphyseal cartilage $(5,6)$. However, the question if pure SM-C/IGF-I will also stimulate true skeletal growth as evidenced by an increase in body length has still not been resolved. In addition it is important to know whether or not overall harmony of body growth is maintained as evidenced by the weight/length relationship and the growth of different organs as is essentially the case with growth hormone $(7,8)$. Scarcity of purified material has hampered extensive studies of the physiological actions of the somatomedins. The recent availability of larger quantities of SM-C/IGF-I synthesized by recombinant DNA technology (9-13) now facilitates such studies. Several analogues of biosynthetic SM-C/IGF-I displayed biological activities similar to SM-C/IGF-I extracted from human plasma derivatives $(9,14-16)$. No data are available concerning the effect of such preparations on body growth. Herein we report the effects of an Escherichia coli derived IGF-I preparation with an amino acid sequence identical to the natural IGF-I on body length and weight, and the growth of several organs of Snell dwarf mice.

\section{MATERIALS AND METHODS}

Snell mice were kept under standardized laboratory conditions $\left(28^{\circ} \mathrm{C}\right.$, humidity $\left.60 \%\right)$ as described earlier (7). Dwarfs were bred by mating heterozygous parents $(\mathrm{dw} /+)$ and by mating heterozygous females to dwarf mice ( $\mathrm{dw} / \mathrm{dw})$, rendered fertile by treatment with $1 \mu \mathrm{g} \mathrm{L}$-thyroxine (Sigma, St. Louis, MO) and $50 \mu \mathrm{g}$ ovine prolactin (Sigma) 5 days a week for at least 3 wk. After weaning at 4-5 wk the dwarfs were maintained on a diet of commercial food pellets, supplemented with a mixture of milk powder, wheat embryo, and raw egg (1:2:2) suspended in $10 \%$ glucose in water. All animals were weighed and the total length was measured weekly by the method of Hughes and Tanner (17) under ether anaesthesia. Groups consisted of five animals $\left(30^{\circ}\right.$, 2 oㅇ, age 6-8 wk) selected such as to obtain equal means and SDs for length and weight.

High protein liquid chromatography pure biosynthetic IGF-I (rec-IGF-I) was from Fujisawa (Osaka, Japan) (13). The specific activity of rec-IGF-I in the radioimmunoassay is $30,000 \mathrm{U} / \mathrm{mg}$. The antiserum is distributed for research use by the National Hormone and Pituitary Distribution Programme of the NIADDK. The effect of bhGH (Abkabi, Stockholm, Sweden; 2 $\mathrm{U} / \mathrm{mg}$ ) on growth of dwarf mice is identical to the effect obtained with hGH derived from cadaver pituitary glands (18). All preparations were dissolved in saline and $0.04 \mathrm{M}$ phosphate buffer (2:1) with $0.1 \%$ human serum albumin (Sigma). The $\mathrm{pH}$ was adjusted with $0.1 \mathrm{~N} \mathrm{NaOH}$ to 7.4 (phosphate buffer).

Animals received $0.1 \mathrm{ml}$ phosphate buffer per injection sup- 
plemented with $2.8 \mu \mathrm{g}$ bhGH, $1.85,3.7$, or $7.4 \mu \mathrm{g}$ rec-IGF-I subcutaneously, three times daily, 5 days a week for $4 \mathrm{wk}$. Buffer alone served as a control.

Body length and weight were measured once per week under light ether anesthesia. After treatment animals were killed by decapitation under ether anaesthesia. For measuring blood glucose levels sera were collected and pooled per group. Organs were removed and weighed to the nearest $\mathrm{mg}$. Statistical analysis of the results was performed according to the S-method of Scheffe (19) or by a Student's $t$ test.

\section{RESULTS}

Body growth. Rec-IGF-I at a dose of $7.4 \mu \mathrm{g} /$ injection and bhGH induced a significant increase in body length and weight compared with phosphate buffer treated controls (Fig. 1). Significance was reached already after 2 wk of treatment. In contrast, 1.85 and $3.7 \mu \mathrm{g}$ rec-IGF-I had only a slight and equal growthstimulating effect. The weight/length ratio of each mouse was calculated at the beginning and the end of the experiment. The means of these ratio's were compared (Table 1). After 4 wk of treatment all groups showed a significant increase of the weight/ length ratio compared to the starting value $(p<0.05)$. Both bhGH and rec-IGF-I $(7.4 \mu \mathrm{g})$ induced a significant but similar increase over the controls. Lower doses of rec-IGF-I yielded intermediate values.

Growth of individual organs and blood glucose levels. The contribution of several organs to the increase in body weight after $4 \mathrm{wk}$ of treatment was studied. In Table 2 the mean organ weights of the different treatment groups are given.

Organs with increased weights after bhGH treatment were also heavier after rec-IGF-I. The magnitude of the increase was not always the same and significance is reached only for musculus quadriceps femoris, the kidneys, and the spleen.

Organ weights expressed as a percentage of body weight of bhGH- and rec-IGF-I-treated dwarfs were not significantly different with one exception: the relative weight of the heart of the bhGH-treated group was significantly increased compared to the rec-IGF-I group and the controls $\left(0.46^{*} \pm 0.02,0.36 \pm 0.01\right.$, and $0.36 \pm 0.02 \%$, respectively). Blood glucose levels after treatment with $1.85,3.7$, and $7.4 \mu \mathrm{g}$ rec-IGF-I were $8.6,7.0$, and $8.0 \mathrm{mmol} /$ liter, respectively. They were slightly lower than those obtained in sera of buffer and bhGH-treated animals (10.6 and 10.6 $\mathrm{mmol} /$ liter, respectively).

\section{DISCUSSION}

Our results demonstrate for the first time that an $E$. coli derived IGF-I preparation with an amino acid sequence identical to the natural IGF-I increases body length and weight as well as the weights of several organs of pituitary-deficient Snell dwarf mice to a comparable degree as obtained after administration of bhGH. This confirms and extends our earlier data concerning the effects of semipurified SM-preparations $(3,4)$.

The overall harmony of growth during treatment with recIGF-I is sustained as shown by the weight/length ratio, which is not significantly different from that of bhGH. In general, organ growth is comparable using either rec-IGF-I or bhGH, although the magnitude of the increase obtained under the present experimental condition is not always the same. Future more detailed studies with higher doses of rec-IGF-I will be needed to establish whether or not there are differences in the effects on specific organs between rec-IGF-I and bhGH.

Table 1. Wt/length ratio of Snell dwarf mice before and after 4 wk administration with phosphate buffer, bhGH, and rec-IGF-I

\begin{tabular}{ccc}
\hline Wreatment & $\begin{array}{c}\text { Wt/length }(\mathrm{g} / \mathrm{cm}) \\
\text { mean } \pm \text { SEM } \\
\text { before treatment }\end{array}$ & $\begin{array}{c}\text { Wt/length }(\mathrm{g} / \mathrm{cm}) \\
\text { mean } \pm \text { SEM } \\
\text { after } 4 \text { wk of } \\
\text { treatment }\end{array}$ \\
\hline Phosphate buffer & $0.60 \pm 0.02$ & $0.71 \pm 0.02$ \\
bhGH $(2.8 \mu \mathrm{g})$ & $0.60 \pm 0.01$ & $0.80 \pm 0.02^{*}$ \\
Rec-IGF-I $(1.85 \mu \mathrm{g})$ & $0.59 \pm 0.01$ & $0.75 \pm 0.02$ \\
$(3.7 \mu \mathrm{g})$ & $0.60 \pm 0.02$ & $0.77 \pm 0.04$ \\
$(7.4 \mu \mathrm{g})$ & $0.60 \pm 0.02$ & $0.81 \pm 0.03^{*}$ \\
\hline
\end{tabular}

* A significant increase ( $p<0.05$, by Student's $t$ test) over controls is obtained with both preparations. There is no significance difference between bhGH and $7.4 \mu \mathrm{g}$ rec-IGF-I-treated animals.
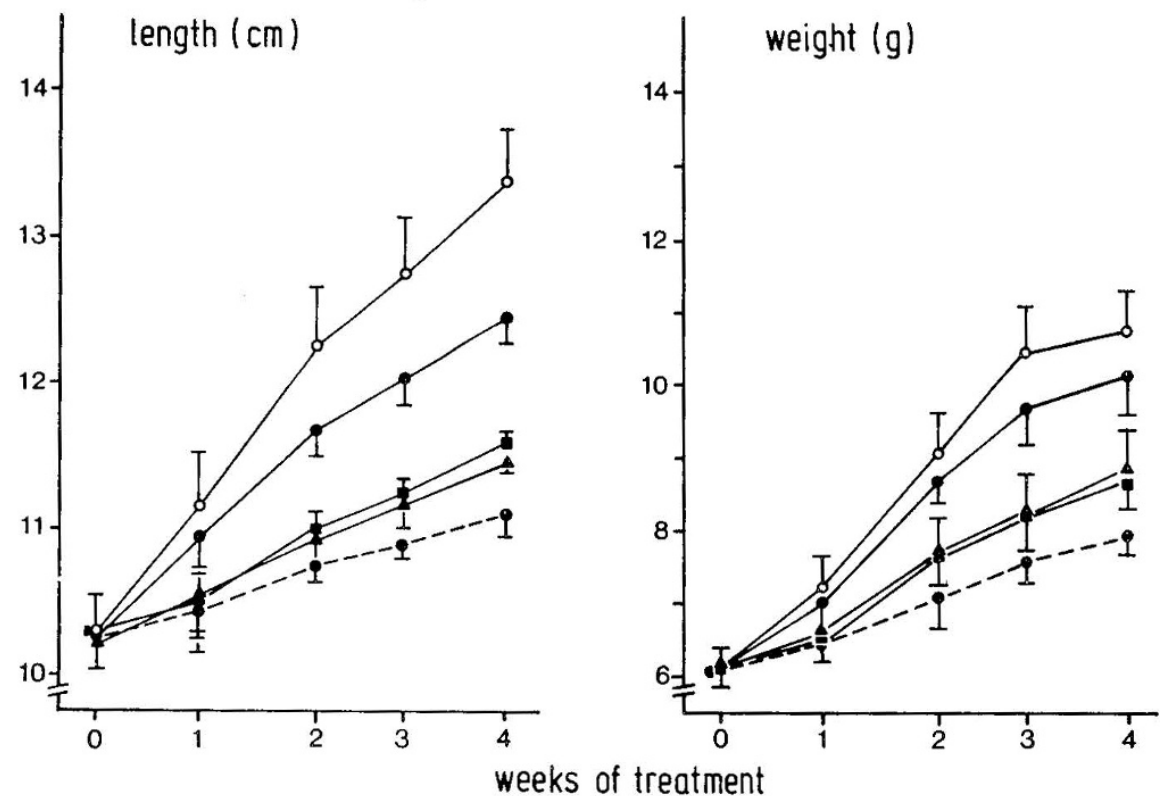

Fig. 1. Length and weight of dwarf mice during treatment with rec-IGF-I and bhGH. Mice received buffer alone (----@); rec-IGF-I 1.85

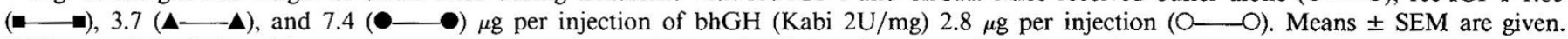
Differences in body length between treated groups and controls were significant after 2 wk of treatment with rec-IGF-I $(7.4 \mu \mathrm{g})(p<0.01)$ and bhGH $(p<0.02)$; differences in body weight relative to the controls were also significant after 2 wk $(p<0.02$ for both substances by Student's $t$ test $)$. There were no significant differences between both substances. 
Table 2. Wet organ wt of dwarf mice after 4 wk of treatment with bhGH and rec-IGF-I

\begin{tabular}{|c|c|c|c|c|c|}
\hline & & & $\mathrm{t}$ in $\mathrm{mg} \pm \mathrm{SEN}$ & & \\
\hline & & & & rec-IGF-I & \\
\hline & Control & bhGH & 1.85 & 3.7 & $7.4 \mu \mathrm{g}$ \\
\hline Body length $(\mathrm{cm})$ & $11.1 \pm 0.1$ & $13.4 \pm 0.4^{*}$ & $11.6 \pm 0.2$ & $11.5 \pm 0.2$ & $12.5 \pm 0.2^{*}$ \\
\hline Body wt & $7860 \pm 271$ & $10,720 \pm 535^{*}$ & $8860 \pm 359$ & $8860 \pm 597$ & $10,160 \pm 501 \dagger$ \\
\hline Brain & $326 \pm 11$ & $370 \pm 8 \dagger$ & $341 \pm 11$ & $342 \pm 11$ & $347 \pm 8$ \\
\hline $\begin{array}{l}\text { Submandibular salivary } \\
\text { glands }\end{array}$ & $23 \pm 2$ & $33 \pm 3 \dagger$ & $28 \pm 3$ & $21 \pm 2$ & $27 \pm 3$ \\
\hline M. quadriceps femoris & $89 \pm 3$ & $105 \pm 8$ & $90 \pm 11$ & $101 \pm 4 \dagger$ & $111 \pm 6 \dagger$ \\
\hline M. gastrocnemius & $94 \pm 10$ & $91 \pm 8$ & $82 \pm 7$ & $96 \pm 6$ & $90 \pm 5$ \\
\hline Heart & $29 \pm 2$ & $49 \pm 3^{*}$ & $33 \pm 3$ & $32 \pm 2$ & $37 \pm 3$ \\
\hline Liver & $409 \pm 18$ & $581 \pm 30^{*}$ & $467 \pm 19$ & $493 \pm 32$ & $490 \pm 44$ \\
\hline Kidneys & $77 \pm 5$ & $134 \pm 11^{*}$ & $97 \pm 7 \dagger$ & $101 \pm 5 \dagger$ & $115 \pm 9^{*}$ \\
\hline Skinfold (back) (mm) & $0.87 \pm 0.02$ & $0.91 \pm 0.05$ & $0.94 \pm 0.06$ & $0.92 \pm 0.06$ & $0.99 \pm 0.05$ \\
\hline Thymus & $22 \pm 2$ & $39 \pm 2 *$ & $26 \pm 2$ & $23 \pm 2$ & $32 \pm 5$ \\
\hline Spleen & $11 \pm 1$ & $24 \pm 3^{*}$ & $24 \pm 2 *$ & $16 \pm 2 \dagger$ & $20 \pm 3 \dagger$ \\
\hline
\end{tabular}

Levels of significance $p<0.05 ; *$ Scheffé test, $\dagger$ Student's $t$ test. Weights of both submandibular salivary glands, kidneys, m. quadriceps femoris and $\mathrm{m}$. gastrocnemius are combined.

Schoenle et al. (5) found a significant increase in body weight of hypophysectomized rats after treatment with 43 and $103 \mu \mathrm{g}$ IGF-I per day during 6 days. In contrast our dwarf mice needed a higher doses of rec-IGF-I relative to body weight for a significant increase of body weight over controls. Due to the longer treatment period we were able to show that one of the most important indices of skeletal growth, namely body length, increased, hereby offering direct evidence supporting the somatomedin hypothesis (2). Our data resolve the issue as to whether or not pure SM-C/IGF-I will induce growth in length and demonstrate the usefulness of recombinant IGF-I in the studies of growth regulation.

Acknowledgments. The authors thank Mr. C. M. Hoogerbrugge and Mr. J. Branger for their excellent technical assistance and Mrs. I. van de Brink for taking care of the mice. The antiserum used was a gift of Drs. L. Underwood and J. J. van Wyk, University of North Carolina, Chapel Hill, NC. bhGH was kindly provided by AB Kabi, Stockholm, Sweden.

\section{REFERENCES}

1. Salmon WD, Daughaday WH 1957 A hormonally controlled serum factor which stimulates sulfate incorporation by cartilage in vitro. $\mathrm{J}$ Lab Clin Med 49:825-836

2. Daughaday WH, Hall K, Raben MS, Salmon WD, Van den Brande JL, van Wyk JJ 1972 Somatomedin: proposed designation for sulphation factor. Nature 235:107

3. van Buul-Offers S, Van den Brande JL 1979 Effect of growth hormone and peptide fractions containing somatomedin activity on growth and cartilage metabolism of Snell dwarfmice. Acta Endocrinol 92:242-257

4. van Buul-Offers S, Van den Brande JL 1979 Plasma fractions containing somatomedin activity. Part II: biological effects in Snell dwarf mice. In Pecile A, Muller EE, eds Growth Hormone and Other Biologically Active Peptides. Excerpta Medica, Amsterdam, pp 103-121

5. Schoenle E, Zapf J, Humbel RE, Froesch ER 1982 Insulin-like growth factor
I stimulates growth in hypophysectomized rats. Nature 296:252-253

6. Schoenle E, Zapf J, Hauri C, Steiner T, Froesch ER 1985 Comparison of in vivo effects of insulin-like growth factors I and II and of growth hormone in hypophysectomized rats. Acta Endocrinol 108:167-174

7. van Buul S, Van den Brande JL 1978 The Snell dwarfmouse I. Acta Endocrinol 89:632-645

8. van Buul S 1984 The effects of pituitary, thyroid, pancreatic and sexual hormones on body length and weight and organ weights of Snell dwarf mice. Growth 48:101-119

9. Peters MA, Lau EP, Snitman DL, van Wyk JJ, Underwood LE, Russell WE, Svoboda ME 1985 Expression of a biologically active analogue of somatomedin-C/insulin-like growth factor I. Gene 35:83-89

10. Buell G, Schulz MF, Selzer G, Chollet A, Rao Movva N, Semon D, Escanez S, Kawashima E 1985 Optimizing the expression in E. coli of a synthetic gene encoding somatomedin-C (IGF-I). Nucl Acids Res 13:1923-1938

11. Sproat BS, Gait MJ 1985 Chemical synthesis of a gene for Somatomedin-C. Nucl Acids Res 13:2959-2977

12. Nilsson B, Holmgren E, Josephson S, Gatenbeck S, Philipson L, Uhlen M 1985 Efficient secretion and purification of human insulin-like growth factor I with a gene fusion vector in staphylococci. Nucl Acids Res 13:1151-1162

13. Niwa N, Sato S, Saito Y, Uchiyama F, Ono H, Yamashita M, Kitaguchi T, Shiga Y, Notani J, Yamada H, Ishii Y, Ueda I, Takagi Y 1984 Chemical synthesis, cloning and expression of genes for human somatomedin $\mathrm{C}$ (insulin-like growth factor I (IGF-I)) and Val-Somatomedin C (Val-IGF-I). Fourth International Biochemical Engineering Conference, Galway, Ireland

14. Schalch D, Reismann D, Emler C, Humbel R, Li CH, Peters M, Lau E 1984 Insulin-like growth factor I/Somatomedin-C (IGF-I/SM-C): comparison of natural solid phase synthetic and recombinant DNA analog peptides in two radioligand assays. Endocrinology 115:2490-2492

15. Horlein D, Buell G, Schultz MF, Hirschi M 1985 Characterization of two forms of Somatomedin-C produced by recombinant bacteria. Sixty-seven 1 Annual Meeting Endocrine Society, Baltimore, 63(abstr 250)

16. Asada T, Seki J, Horiai T, Motoyama Y, Ogawa R, Ono T, Kikuchi H 1985 Bioactivity of IGF-I/somatomedin-C produced by recombinant DNA technology. Folia Endocrinol Jpn 61:1030(abstr 351)

17. Hughes PCR, Tanner JM 1970 A longitudinal study of the growth of the blackhooded rat: methods of measurement and rates of growth for skull, limbs, pelvis, nose-rump and tail lengths. J Anat 106:349-370

18. van Buul-Offers S, Van den Brande JL 1985 Biosynthetic human growth hormone: effects of growth of Snell dwarf mice. Horm Metab Res 17:20-24

19. Scheffe H 1959 The Analysis of Variance. Wiley, New York 